PROFESI (Profesional Islam)

Media Publikasi Penelitian; 2018; Volume 15; No 2.

Website: ejournal.stikespku.ac.id

\title{
Peningkatan Pengetahuan, Sikap dan Kepatuhan Melalui Konseling Nutrisi pada Ibu Hamil Anemia di Kabupaten Pringsewu
}

\author{
Desi Ari Madi Yanti $^{(1)}$, Apri Sulistianingsih ${ }^{(1)}$, Sumi Anggraeni ${ }^{(1)}$ \\ arimadiyantidesi@yahoo.com, sulistianingsih.apri@gmail.com, \\ affan.ummi@gmail.com, stikesmuh-pringsewu.ac.id \\ ${ }^{1}$ Tenaga pendidik STIKes Muhammadiyah Pringsewu
}

\begin{abstract}
Kata Kunci
Anemia,

Kehamilan,

Konseling,

Nutrisi
\end{abstract}

\begin{abstract}
Abstrak
Kebutuhan besi selama kehamilan meningkat seiring dengan usia kehamilan. Ibu hamil yang tidak memenuhi kebutuhan nutrisi baik dari makanan dan suplemen besi dapat berisiko terhadap anemia defisiensi besi kehamilan. Anemia dapat menyebabkan morbiditas dan mortalitas bagi ibu dan janin. Ibu hamil yang mengalami anemia perlu diberikan konseling nutrisi yang teratur untuk menatalaksana anemia agar anemia dapat tertangani. Subjek dalam penelitian ini adalah ibu hamil yang berkunjung pertama kali di di BPM (Bidan Praktik mandiri) di Wilayah Kabupaten Pringsewu Lampung. Desain penelitian ini adalah quasi eksperiment dengan pre-post test design. Pada awal kunjungan ibu dilakukan screening anemia dengan pemeriksaan hemoglobin, ibu hamil yang anemia kemudian diukur pengetahuan, sikap dan kepatuhan konsumsi suplemen besi. Ibu kemudian mendapatkan konseling nutrisi tentang penatalaksanaan anemia dan dievaluasi kembali setelah 2 minggu penelitian. kemudian hasil dari 2 pengukuran akan dianalisis.t paired dan analisis multivariat menggunakan Multiple Regression Analysis. Hasil penelitian menjelasakan bahwa. Ada perbedaan signifikan pada pengetahuan, sikap dan kepatuhan konsumsi tablet besi pada sebelum dan setelah penelitian. Peningkatan pengetahuan dan kepatuhan konsumsi tablet besi berpengaruh terhadap peningkatan kadar hemoglobin. berdasarkan hasil penelitian didapatkan bahwa pengetahuan dan kepatuhan memberikan pengaruh sebesar 75\% terhadap peningkatan kadar hemoglobin.
\end{abstract}

\section{The Improvement of Knowledge, Attitude and Compliance Through Nutrition Counselling in Anemia Pregnant Woman in Pringsewu}

\section{Keywords}

Anemia, Pregnancy, Counseling, Nutrition

\section{Abstract}

The need for iron during pregnancy increases corresponding with the age of pregnancy. Pregnant women who do not meet the nutritional needs both of food and iron supplements may be at risk for iron deficiency anemia. Anemia can cause maternal and fetal morbidity and mortality. Pregnant women with anemia need to be given regular nutrition counseling to manage anemia for anemia can be handled. Objecetive: The aim of this study to know the effect of nutritional counselling to improve knowledge, attitude and compliance of consumption of iron supplements in anemia pregnant woman in Pringsewu district. Methods: The Subjects in this study were pregnant women who first visited at the BPM (Independent Practice Midwife) in Pringsewu District Lampung. The design of this research was quasi experiment with pre-post test design. At the beginning of the visit the mother was screened anemia by examination of hemoglobin, anemia pregnant women then measured their knowledge, attitude and compliance consumption of iron supplement. The 
PROFESI (Profesional Islam)

Media Publikasi Penelitian; 2018; Volume 15; No 2.

Website: ejournal.stikespku.ac.id

mother then received nutritional counseling about anemia management and reevaluated after 2 weeks of study. Then the result of 2 measurements will be analyzed.t paired and multivariate analysis using Multiple Regression Analysis. Result:The results of the study showed that. There were significant differences in knowledge, attitude and compliance of iron tablets consumption before and after the study $(\rho<0,05)$. Increased knowledge and compliance consumption of iron tablets affect the increase in hemoglobin levels. Based on the results of the study is found that knowledge and compliance gives the effect of $75 \%$ to increase hemoglobin levels. Conclucion: There are significant differences in knowledge, attitude and compliance of iron tablets consumption before and after the study

\section{PENDAHULUAN}

Berdasarkan dari laporan Riset Kesehatan Dasar (RISKESDAS) tahun 2013 menyatakan bahwa kepatuhan ibu hamil dalam mengkonsumsi TTD selama 90 hari hanya 33.3\%, sedangkan provinsi dengan asupan zat besi 90 hari terandah merupakan provinsi Lampung sebesar 15,4\%.(Riskesdas, 2013) Kondisi ini diperparah dengan perilaku ibu hamil mengkonsumsi makanan yang mengandung energi, karbohidrat, protein, lemak dan besi masih di bawah rata - rata rekomendasi Depkes RI tahun 1998, sehingga pemenuhan gizi masih merupakan masalah yang serius bagi ibu hamil terutama asupan besi dari makanan baru terpenuhi 34,35\%.(Mariyam S, Yuliati, \& Rahayu $\mathrm{T}, 2007)$

Berdasarkan profil kesehatan kabupaten Pringsewu tahun 2014 terlihat sangat rendahnya prevalensi anemia yaitu $0,5 \%$. Rendahnya prevalensi ini tidak dibarengi dengan kasus BBLR yang justru lebih besar yaitu sebesar 21,5\% (Profil Kesehatan Kabupaten Pringsewu, 2014) sedangkan kasus BBLR di tingkat nasional saja hanya mencakup 7,7\% (SDKI, 2012). Setelah dilakukan pra survey ulang pada bulan oktober 2014 didapatkan ternyata prevalensi anemia mencapai $44 \%$. Penyebab tingginya prevalensi anemia terlihat dari asupan zat besi dari pola diet yang rata - rata hanya $\mathrm{mg}$, dan ibu hamil yang patuh minum zat besi selama 90 hari hanya $32 \%$

Anemia pada kehamilan akan menyebabkan gangguan pertukaran nutrisi dan oksigen pada ibu dan janin. Dampak bagi ibu hamil yang menderita anemia dapat terjadi gangguan aktivitas, persalinan lama, perdarahan pada persalinan, infeksi nifas hingga kematian ibu. Anemia yang disebabkan oleh defisiensi besi menyumbang $18 \%$ kematian ibu.(Kalaivani, 2009; Koura GK et al., 2012) Pada janin dapat menyebabkan gangguan pertumbuhan, persalinan prematur, Bayi Berat Lahir Rendah (BBLR) sampai pada kematian bayi.(Allen LH, 2000; Burke RM, Leon JS, \& Suchdev PS, 2014; Kalaivani, 2009; Koura GK et al., 2012; Lawn JE, Causens S, \& Zupan J, 2005; Stoltzfus RJ, 2011) Mortalitas dan morbiditas pada ibu dan janin dapat dicegah dengan meningkatkan asupan nutrisi dan suplementasi besi pada ibu hamil.

Upaya preventif untuk mencegah terjadinya anemia dilakukan dengan deteksi dini melalui pemeriksaan hemoglobin pada trimester pertama. Bentuk asuhan yang dilakukan adalah program pemberian suplementasi besi selama 90 hari kehamilan dengan dosis $60 \mathrm{mg}$ dan konseling nutrisi kehamilan.(Thorand B, Schultink W, Gross R, Sastroamidjojo S, \& Wentzel S, 1994) Hal ini sesuai dengan rekomendasi WHO dalam pencegahan anemia dalam bentuk: suplemen besi pada ibu hamil, fortifikasi besi pada makanan, pendidikan kesehatan tentang nutrisi dan gaya hidup ibu hamil.(WHO, 2012a, 2012b)

Menurut hasil penelitian yang dilakukan oleh Garg tahun 2006 bahwa konseling teratur dan bertahap selama kehamilan berpengaruh terhadap peningkatan status gizi ibu hamil. Dalam penelitian ini mempromosikan 6 hal penting yaitu: promosi kualitas dan kuantitas pola diet, promosi dalam meningkatkan asupan suplemen zat besi, istirahat selama kehamilan, imunisasi Tetanus Toxoid (TT) dan menggunakan garam beryodium.(Garg A \& Kashyap S, 2006)

Hasil yang sama juga ditemukan pada penelitian Billimale tahun 2010 bahwa ibu yang berulangkali diberikan penguatan konseling 
anemia lebih patuh mengkonsumsi zat besi. dengan diberikan penguatan konseling yang dilakukan berkala dalam jangka waktu $2-4$ minggu sekali maka penyebab utama ketidak patuhan ibu dalam mengkonsumsi zat besi yaitu karena lupa dapat diatasi.(Bilimale A, Anjum J, Sangolli HN, \& Mallapur M, 2010)

Penelitian ini bertujuan untuk mengetahui pengaruh konseling nutrisi terhadap pengetahuan, sikap dan kepatuhan konsumsi suplemen besi pada ibu hamil anemia di Kabupaten Pringsewu Lampung.

Penelitian ini bertujuan untuk mengetahui pengaruh konseling nutrisi terhadap pengetahuan, sikap dan kepatuhan konsumsi suplemen besi pada ibu hamil anemia di Kabupaten Pringsewu Lampung.

\section{Metode Penelitian}

Penelitian pengaruh konseling nutrisi terhadap pengetahuan, sikap dan kepatuhan konsumsi suplemen besi pada ibu hamil anemia di Kabupaten Pringsewu Lampung. Pengetahuan, sikap dan kepatuhan konsumsi suplemen besi dapat meningkatkan kadar hemoglobin pada ibu hamil anemia.

Penelitian ini menggunakan desain quasi eksperiment dengan pre-post test without control. Subjek pada penelitian ini ibu hamil anemia berkunjung ke BPM wilayah pringsewu.

Sampel penelitian berjumlah38 orang. Kriteria inklusi dalam penelitian ini adalah Ibu ibu hamil anemia yang datang berkunjung ke BPM dan bersedia menjadi responden dengan menandatangani persetujuan setelah penjelasan (PSP), kriteria eksklusi adalah Ibu hamil dengan gemelli Ibu hamil yang didiagnosis oleh dokter menderita infeksi. Sebelum penelitian, subjek diberikan kuesioner pre test kemudian perlakuan yang akan diberikan pada penelitian ini berupa konseling nutrisi dalam bentuk panduan konseling dengan waktu pemberian sekitar 30-40 menit kemudian pada waktu 2 minggu setelah penelitian didapatkan hasil post test penelitian. Analisis dalam penelitian ini adalah analisis univariat dan bivariat dan multivariat untuk menganalisis hubungan antara variabel bebas dan variabel terikat

\section{Hasil Penelitian}

Gambaran Karakteristik Ibu Hamil dengan Anemia di Wilayah Kabupaten Pringsewu Lampung

Karakteristik pada subjek penelitian disajikan untuk mengetahui gambaran subjek penelitian. Pada penelitian ini karakteristik meliputi umur, umur kehamilan, gravida, pendidikan, penghasilan, status gizi (Indeks Masa Tubuh (IMT) sebelum kehamilan, dan Lingkar Lengan Atas (Lila) pada K1)

Berdasarkan tabel 1 didapatkan data karakteristik ibu hamil. Pada data umur didapatkan rata-rata adalah $30,4(6,24)$. Jumlah pendidikan terbanyak adalah pendidikan SMA/ Sederajat. Jumlah penghasilan setiap bulannya didapatkan nilai rata-rata Rp.1.625.000 (762.441). sebagian besar ibu hamil adalah multigravida $(73,7)$ dengan rata-rata umur kehamilan 24,1 minggu. Berdasarkan data status gizi ibu didapatkan ratarata Indeks Masa Tubuh (IMT) ibu adalah $21,3(2,97)$ dan lingkar lengan atas pada kunjungan $\mathrm{K} 1$ adalah $25,4(3,65)$.

\section{Perbedaan Pengetahuan, Sikap dan Kepa- tuhan Konsumsi Suplemen Besi Sebelum dan Setelah Penelitian}

Pada tabel berikut dijelaskan hasil analisis nilai pengetahuan, sikap dan kepatuhan sebelum dan setelah penelitian. Hal ini bertujuan untuk melihat perbedaan masing-masing variabel. 
PROFESI (Profesional Islam) Media Publikasi Penelitian; 2018; Volume 15; No 2.

Website: ejournal.stikespku.ac.id

Tabel 1 Karakteristik subjek penelitian

\begin{tabular}{|c|c|c|}
\hline Karakteristik & $\mathrm{N}$ & Persentase \\
\hline \multicolumn{3}{|l|}{ Umur (Tahun) } \\
\hline $\mathrm{x}(\mathrm{SD})$ & $30,4(6,24)$ & \\
\hline median & 32,5 & \\
\hline Rentang & $19-40$ & \\
\hline \multicolumn{3}{|l|}{ Pendidikan } \\
\hline $\mathrm{SD} /$ Sederajat & 4 & 10,5 \\
\hline SMP/Sederajat & 13 & 34,2 \\
\hline SMA/Sederajat & 17 & 44,7 \\
\hline PT/Sederajat & 4 & 10,5 \\
\hline \multicolumn{3}{|l|}{ Penghasilan } \\
\hline $\mathrm{x}(\mathrm{SD})$ & $1.625 .000(762.441)$ & \\
\hline median & 1.500 .000 & \\
\hline Rentang & $700.000-3.500 .000$ & \\
\hline \multicolumn{3}{|l|}{ Gravida } \\
\hline Primigravida & 10 & 26,3 \\
\hline Multigravida & 28 & 73,7 \\
\hline \multicolumn{3}{|c|}{ Umur Kehamilan (Minggu) } \\
\hline $\mathrm{x}(\mathrm{SD})$ & $24,1(4,85)$ & \\
\hline Median & 24,0 & \\
\hline Rentang & $14-36$ & \\
\hline \multicolumn{3}{|l|}{ Status Gizi } \\
\hline \multicolumn{3}{|l|}{ IMT Sebelum Hamil $\left(\mathrm{Kg} / \mathrm{m}^{2}\right)$} \\
\hline $\mathrm{x}(\mathrm{SD})$ & $21,3(2,97)$ & \\
\hline Median & 21,0 & \\
\hline Rentang & $17-32$ & \\
\hline \multicolumn{3}{|l|}{ LiLa K1 (Cm) } \\
\hline $\mathrm{x}(\mathrm{SD})$ & $25,4(3,65)$ & \\
\hline Median & 24,25 & \\
\hline Rentang & $20-40$ & \\
\hline
\end{tabular}

Tabel 2 Perbedaan Pengetahuan, Sikap dan Kepatuhan Konsumsi Suplemen Besi Sebelum Dan Setelah Penelitian

\begin{tabular}{cllc}
\hline Keterangan & \multicolumn{3}{c}{ Subjek penelitian $(\mathbf{n}=\mathbf{3 8})$} \\
\cline { 2 - 4 } & \multicolumn{1}{c}{ Pre test } & \multicolumn{1}{c}{ Post test } & Nilai $\boldsymbol{\rho}$ \\
\hline Pengetahuan & \multicolumn{3}{c}{ Pron } \\
x (SD) & $65,6(10,30)$ & $80,8(12,17)$ & $0,028^{*}$ \\
Median & 67,0 & 81,0 & \\
Rentang & $39-82$ & $43-100$ & $0,002^{*}$ \\
Sikap & & & \\
x (SD) & $60,6(11,86)$ & $76,6(11,37)$ & \\
Median & 60,0 & 75,0 & \\
Rentang & $36-88$ & $50-90$ & \\
Kepatuhan & & & \\
x (SD) & $40,3(25,65)$ & $74,9(24,61)$ & \\
Median & 25,0 & 84,0 & \\
Rentang & $4-79$ & $14-100$ & \\
\hline
\end{tabular}

Keterangan uji : *) T Paired, **) uji Wilcoxon 
PROFESI (Profesional Islam)

Media Publikasi Penelitian; 2018; Volume 15; No 2.

Website: ejournal.stikespku.ac.id

Berdasarkan tabel 4.2 didapatkan bahwa ada perbedaan signifikan pada pengetahuan, sikap dan kepatuhan konsumsi tablet besi pada sebelum dan setelah penelitian $(\rho<0,05)$.
Pada tabel berikut dijelaskan hasil analisis nilai pengetahuan, sikap dan kepatuhan sebelum dan setelah penelitian. Hal ini bertujuan untuk melihat perbedaan masing-masing variabel.

Tabel 3 Perbedaan kadar hemoglobin ibu hamil Sebelum dan Setelah Penelitian

\begin{tabular}{llll}
\hline Keterangan & \multicolumn{3}{c}{ Subjek penelitian $(\mathrm{n}=38)$} \\
\cline { 2 - 4 } & \multicolumn{2}{c}{ Pre test test } & Nilai $\rho$ \\
\hline Kadar Hemoglobin & $9,75(0,84)$ & $10,04(0,98)$ & $<0,001^{*}$ \\
x (SD) & 9,85 & 10,10 & \\
Median & $8-11$ & $8-12$ & \\
Rentang & & & \\
\hline
\end{tabular}

Keterangan uji : *) Uji Wilcoxon

Berdasarkan tabel 3 didapatkan bahwa ada perbedaan signifikan kadar hemoglobin sebelum dan setelah penelitian $(\rho=<0,001)$

Pada tabel berikut akan dijelaskan hasil regresi peningkatan kadar hemoglobin berdasar- kan variabel pengetahuan, sikap dan kepatuhan. Hal ini bertujuan untuk melihat besarnya pengaruh pengetahuan, sikap dan kepatuhan terhadap peningkatan kadar hemoglobin.

Tabel 4 Pengaruh Peningkatan Pengetahuan, Sikap dan Kepatuhan terhadap Peningkatan Kadar Hemoglobin pada Ibu Hamil Anemia

\begin{tabular}{|c|c|c|c|c|c|c|}
\hline \multicolumn{7}{|l|}{ 1. Model Awal } \\
\hline Keterangan & B & SE beta & Beta & $\mathbf{P}$ & $\mathbf{R}$ & $\mathbf{R}^{2}$ \\
\hline Delta pengetahuan & 0,013 & 0,005 & 0,363 & 0,009 & 0,876 & 0,767 \\
\hline Delta Sikap & 0,007 & 0,002 & 0,167 & 0,176 & & \\
\hline Delta Kepatuhan & 0,006 & 0,100 & 0,447 & 0,001 & & \\
\hline Konstanta & $-0,613$ & 0,129 & - & & & \\
\hline \multicolumn{7}{|l|}{ 2. Model Akhir } \\
\hline Keterangan & B & SE beta & Beta & $\mathbf{P}$ & $\mathbf{R}$ & $\mathbf{R}^{2}$ \\
\hline Delta pengetahuan & 0,016 & 0,004 & 0,444 & 0,001 & 0,868 & 0,753 \\
\hline Delta Kepatuhan & 0,007 & 0,002 & 0,496 & 0,000 & & \\
\hline Konstanta & $-0,501$ & 0,100 & - & & & \\
\hline
\end{tabular}

Keterangan uji : Multiple Regression Analysis

Berdasarkan tabel 4 didapatkan bahwa peningkatan pengetahuan dan kepatuhan konsumsi tablet besi berpengaruh terhadap peningkatan kadar hemoglobin. berdasarkan hasil penelitian didapatkan bahwa pengetahuan dan kepatuhan memberikan pengaruh sebesar $75 \%$ terhadap peningkatan kadar hemoglobin

\section{PEMBahasan}

Di Indonesia masih banyak ibu hamil dengan status gizi kurang seperti kurus atau menderita anemia. Hal ini disebabkan asupan makanan yang tidak cukup bagi ibu dan janin. Beban kerja ibu hamil biasanya sama atau lebih berat dibandingkan sebelum hamil, akibatnya bayi tidak mendapatkan zat gizi yang dibutuhkan sehingga mengganggu pertumbuhan dan perkembangan janin.(Kementerian Kesehatan RI, 2014)

Di Indonesia prevalensi anemia ibu hamil tahun 2013 menujukkan 37,1\%. Kondisi ini masih menunjukkan bahwa anemia merupakan masalah di Indonesia.(Badham J \& Zimmermann MB, 2007) Berdasarkan profil kesehatan kabupaten Pringsewu tahun 2014 terlihat sangat 
PROFESI (Profesional Islam)

Media Publikasi Penelitian; 2018; Volume 15; No 2.

Website: ejournal.stikespku.ac.id

rendahnya prevalensi anemia yaitu $0,5 \%$. Rendahnya prevalensi ini tidak dibarengi dengan kasus BBLR yang justru lebih besar yaitu sebesar 21,5\% (Profil Kesehatan Kabupaten Pringsewu, 2014) sedangkan kasus BBLR di tingkat nasional saja hanya mencakup 7,7\% (SDKI, 2012). Setelah dilakukan pra survey ulang pada bulan oktober 2014 didapatkan ternyata prevalensi anemia mencapai $44 \%$. Penyebab tingginya prevalensi anemia terlihat dari asupan zat besi dari pola diet yang rata - rata hanya $\mathrm{mg}$, dan ibu hamil yang patuh minum zat besi selama 90 hari hanya $32 \%$

Frekuensi terjadinya anemia tergantung pada status besi sebelum kehamilan. Faktor determinan dari defisiensi besi dikarenakan rendahnya penghasilan dan kemiskinan yang menyebabkan secara umum rendahnya asupan makanan, makanan yang monoton dengan rendah mikronutrien.(Garg A \& Kashyap S, 2006; Thompson $B$, 2008) Anemia juga disebabkan karena rendahnya pengetahuan tentang pentingnya sumber makanan yang bervariasi dan kaya mikronutrien. Kondisi ini sejalan dengan rendahnya pengetahuan tentang faktor penguat dan penghambat dalam penyerapan besi.(Thompson B, 2008).

Faktor risiko terjadinya anemia dimulai dari politik ekonomi negara yang dipengaruhi oleh ekologi, iklim dan geografi. Ekonomi negara dapat mempengaruhi pendidikan, pendapat, budaya dan perilaku.(Balarajan, Ramakrishnan U, Ozaltin E, Shankar AH, \& Subramanian SV, 2011) Kondisi tersebut memberikan pengaruh terhadap asupan keseharian sehingga akan berpengaruh pada status gizi ibu sebelum kehamilan. Status gizi ini dapat dilihat dari indeks masa tubuh dan lingkar lengan atas. Hal ini tentu saja akan berdampak pada subjek rentan terutama ibu hamil dengan paritas tinggi. (Riskesdas, 2013)

Pada saat penelitian, peneliti melakukan standarisasi modul pendidikan konseling kepada enumerator. Peneliti kemudian melakukan konseling yang terjadwal pada subjek penelitian untuk meningkatkan pengetahuan, sikap dan kepatuhan konsumsi tablet besi

Proses antenatal care yang terlalu lama terkadang membuat ibu hamil menjadi lelah dan tidak bisa berkonsentrasi dalam mengikuti konseling. Dalam mengatasi hal tersebut peneliti untuk memberikan koseling di rumah agar proses penelitian dapat berjalan.
Berdasarkan tabel 4.2 didapatkan bahwa adanya perbedaan signifikan pengetahuan, sikap dan kepatuhan konsumsi tablet besi sebelum dan setelah penelitian Pada saat seseorang diberikan informasi secara tepat tentang perilaku kesehatan dan dimotivasi dengan baik untuk melakukan perubahan perilaku.(Osborn CY, Amico K, Disher WA, Egede LE, \& Fisher J, 2010) Dampak pemberian pendidikan nutrisi juga akan meningkatkan kesadaran tentang risiko anemia defisiensi besi. Sehingga terbentuk sikap untuk mengatasi anemia (Yusoff $\mathrm{H}$, Daud WNW, \& Ahmad Z, 2013) Contohnya kepercayaan yang timbul karena ingin sembuh dari anemia dan persalinan yang lancar, maka ibu hamil memiliki kepercayaan diri dalam keterampilan untuk menatalaksana anemia. Informasi, motivasi dan keterampilan tidak selalu berhubungan langsung dengan luaran perilaku (Perubahan kadar hemoglobin) tetapi merupakan perantara terbentuknya pengetahuan, sikap dan keterampilan untuk terbentuk perilaku yang diinginkan (kepatuhan konsumsi TTD dan asupan makanan).

Pendidikan nutrisi dan konseling secara umum meningkatkan asupan makan ibu hamil termasuk praktik asupan tentang mikronutrien dan makronutrien secara spesifik seperti sayuran hijau dan protein. Terdapat dua puluh penelitian menyatakan bahwa dampak pendidikan nutrisi yang terstruktur mampu meningkatkan kuantitas dan jenis asupan makro serta mikronutrien. (Girard AW \& olude O, 2012) Saran diet yang berlebihan dan tidak focus juga dapat membuat ibu hamil menjadi bingung dan susah untuk mengikuti saran dari tenaga kesehatan.(Ferrari RM, Siega-Riz AM, Evenson KR, Moos MK, \& Carrier KS, 2013)

Anemia disebabkan tidak optimalnya nutrisi yang diperlukan bagi pembentukan eritrosit. Selain itu, hal ini juga dapat disebabkan oleh faktor penguat dan penghambat dalam penyerapan besi. Hal ini diperparah karena selama kehamilan, kebutuhan besi ibu semakin meningkat yang tidak cukup hanya dengan kebutuhan dari makanan saja tapi harus dipenuhi dengan suplementasi TTD. Sayangnya kepatuhan ibu dalam konsumsi TTD tidak sebaik yang diharapkan.(Riskesdas, 2013)

Suplementasi besi yang dikonsumsi secara teratur dapat mengurangi risiko terjadinya anemia selama kehamilan dan menurunkan risiko 
terjadinya BBLR. TTD dapat menimbulkan efek samping yang kurang menyenangkan seperti mual, konstipasi, diare dan feces hitam. Efek samping tersebut dapat mempengaruhi kepatuhan konsumsi TTD. Selain itu cara minum yang tidak tepat dapat menyebabkan penyerapan dari TTD menjadi tidak maksimal (Hyder SMZ, Persson LA, Chowdhury AMR, \& Ekstrom EC, 2002; Souza AID, Filho MB, Bresani CC, Ferreira LOC, \& Figueiroa JN, 2009; Thirukkanesh S \& Zahara AM, 2010)

Salah satu upaya dalam meningkatkan kepatuhan konsumsi TTD adalah dengan memberikan informasi tentang penatalaksanaan anemia, meningkatkan pemahaman tentang pentingnya suplementasi besi dan memberikan informasi tentang kepercayaan yang tidak benar tentang tablet tambah darah. Pengawasan pemberian TTD dari tenaga kesehatan dan konseling secara teratur dapat meningkatkan kepatuhan konsumsi TTD.(Bilimale A et al., 2010)

Sebanyak enam penelitian menyebutkan bahwa pendidikan nutrisi berdampak pada kepatuhan konsumsi suplementasi yang direkomendasikan.(Girard AW \& olude O, 2012) Ibu hamil yang mendapatkan pendidikan nutrisi atau konseling akan lebih patuh dalam mengkonsumsi suplementasi besi.(Garg A \& Kashyap S, 2006) Pada penelitian ini terlihat bahwa kelompok kontrol juga mengalami peningkatan yang bermakna terhadap kepatuhan konsumsi tablet tambah darah. Adanya proses belajar tentang pentingnya suplementasi dapat meningkatkan kesadaran ibu dalam mengkonsumsi TTD secara teratur.

Kepatuhan konsumsi tablet tambah darah ini sangat penting dikarenakan kebutuhan besi selama kehamilan tidak dapat dipenuhi hanya dari makanan saja.(Beaton GH, 2000) Kepatuhan konsumsi TTD perlu ditingkatkan dan membutuhkan keterampilan khusus. Efek samping yang kurang menyenangkan dari tablet tambah darah dapat mempengaruhi kepatuhan, selain itu TTD juga mudah terpengaruh oleh faktor penguat dan penghambat, diperlukan keterampilan untuk meningkatkan kepercayaan diri ibu dalam mengkonsumsi TTD dan mengurangi efek samping dari TTD.

Keterampilan ini dapat dibangun dari pengetahuan dan sikap ibu. Sehingga diperlukan juga motivasi dan informasi yang akurat terkait TTD. Adanya informasi dan motivasi ini dapat membangun pengetahuan dan sikap ibu dalam menerima TTD. Ibu memiliki sikap yang terbuka dalam melakukan keterampilan dalam mengurangi efek samping TTD dan penyerapan TTD tidak terganggu

Ibu hamil normal setidaknya membutuhkan cadangan besi sekitar $300 \mathrm{mg}$. Cadangan ini diperlukan untuk memenuhi kebutuhan besi selama kehamilan.(Bothwell TH, 2000) Hal ini disebabkan karena kebutuhan besi selama kehamilan meningkat sampai $1.240 \mathrm{mg}$ dan tidak dapat dipenuhi dari asupan makan saja. Ibu hamil yang mengalami kekurangan cadangan besi apalagi sampai menderita anemia sangat berisiko pada kehamilannya.(Milman N, 2012) Risiko akan meningkat sesuai dengan keparahan anemia dan usia kehamilan.

Ibu hamil dengan anemia sedang berisiko mengalami luaran persalinan yang buruk seperti prematur, perdarahan dan BBLR.(Kalaivani, 2009) Risiko ini semakin meningkat apabila kondisi anemia terus berlanjut sampai pada akhir persalinan dan dapat menyebabkan anemia berat. Ibu hamil akan kesulitan melakukan pekerjaan termasuk pada pekerjaan rumah dan mengurus anak.

Berdasarkan tabel 4.3 didapatkan bahwa ada perbedaan signifikan kadar hemoglobin sebelum dan setelah penelitian $(\rho=<0,001)$. Sejalan dalam kajian Girard tahun 2012 menyatakan bahwa ibu hamil yang diberikan pendidikan nutrisi dapat meningkatkan kesembuhan pada pasien anemia. Pendidikan nutrisi ini mampu meningkatkan asupan makanan ibu lebih kaya protein dan sayuran, selain itu ibu hamil lebih patuh mengkonsumsi suplementasi besi bila dibandingkan dengan ibu yang tidak mendapatkan pendidikan nutrisi.(Girard AW \& olude O, 2012)

Ibu hamil yang diberikan konseling secara teratur di akhir penelitian dapat meningkatkan kadar hemoglobin secara signifikan. Hal ini karena informasi tentang penatalaksanaan anemia dapat diterima ibu dan terjadi proses belajar

Dalam penelitian ini konseling nutrisi, tidak memberikan dampak langsung terhadap peningkatan kadar hemoglobin. Konseling nutrisi memfasilitasi meningkatnya pengetahuan, sikap dan kepatuhan konsumsi tablet besi yang berkorelasi dengan kadar hemoglobin. 
PROFESI (Profesional Islam)

Media Publikasi Penelitian; 2018; Volume 15; No 2.

Website: ejournal.stikespku.ac.id

Berdasarkan tabel 4. 4 didapatkan bahwa peningkatan pengetahuan dan kepatuhan konsumsi tablet besi berpengaruh terhadap peningkatan kadar hemoglobin. berdasarkan hasil penelitian didapatkan bahwa pengetahuan dan kepatuhan memberikan pengaruh sebesar $75 \%$ terhadap peningkatan kadar hemoglobin.

Proses konsleing nutrisi dalam meningkatkan kadar hemoglobin merupakan serangkaian korelasi yang kompleks. Dibutuhkan informasi untuk membangun pengetahuan, sikap. Hal inilah yang nantinya akan membentuk dan kepatuhan konsumsi tablet besi yang tepat sehingga dapat meningkatkan kadar hemoglobin. (Girard AW \& olude O, 2012)

Rendahnya ibu hamil mematuhi konseling nutrisi dijelaskan dalam penelitian Ferarri tentang konseling nutrisi oleh tenaga kesehatan yang menyatakan bahwa sebagian besar ibu tidak dapat mengikuti anjuran konseling nutrisi yang disebabkan oleh beberapa faktor yaitu: konseling nutrisi tidak fokus, terlalu berlebihan, ibu tidak dapat mengaplikasikan karena tidak tahu caranya dan lupa materi konseling. Berdasarkan fakta tersebut dapat disimpulkan bahwa konseling nutrisi dan suplementasi besi yang selama ini dilakukan guna mengatasi anemia dinilai belum maksimal. Pada penelitian ini dapat dilihat pada akhir penelitian rata - rata kadar Hemoglobin adalah 10,04(0,98)(Ferrari RM et al., 2013). Hal ini masih masuk kedalam kategori anemia ringan(WHO, 2011)

Salah satu kekurangan dari penelitian ini adalah, peneliti tidak melakukan pengukuran asupan gizi pada ibu hamil. Sehingga peneliti tidak dapat melakukan perhitungan besarnya pengaruh asupan makanan terhadap peningkatan kadar hemoglobin.

\section{KESIMPULAN}

Ada perbedaan signifikan pada pengetahuan, sikap dan kepatuhan konsumsi tablet besi pada sebelum dan setelah penelitian. Peningkatan pengetahuan dan kepatuhan konsumsi tablet besi berpengaruh terhadap peningkatan kadar hemoglobin. berdasarkan hasil penelitian didapatkan bahwa pengetahuan dan kepatuhan memberikan pengaruh sebesar $75 \%$ terhadap peningkatan kadar hemoglobin

\section{Saran}

Bidan diharapkan dapat memberikan asuhan pada ibu hamil anemia dengan memberikan pendidikan kesehatan berkala menggunakan lembar balik maupun aplikasi lain dan dipantau peningkatan kadar hemoglobin agar luaran persalinannya baik

\section{UCAPAN TERIMA KASIH}

Ucapan terima kasih kami sampaikan kepada Kementerian Riset dan Pendidikan Tinggi yang telah memfasilitasi dana penelitian. Dinas Kabupaten Pringsewu, BPM Pringsewu dan LP3M STIKes Muhammadiyah Pringsewu yang memfasilitasi kami dalam melakukan penelitian.

\section{REFERENSI}

Allen LH. (2000). Anemia and Iron Deficiency: effecs on Pregnancy outcome. The American Journal of Clinical Nutrition, 2000(7), 5 .

Badham J, \& Zimmermann MB. (2007). The Guide Book Of Nutritional Anemia

Balarajan, Ramakrishnan U, Ozaltin E, Shankar AH, \& Subramanian SV. (2011). Anemia in Low-Income and Middle Income Countries. Lancet, 378(12), 2123.

Beaton GH. (2000). Iron needs during pregnancy: do we need to rethink our targets? $A m \mathrm{~J}$ Clin Nutr, 2000(72), 7.

Bilimale A, Anjum J, Sangolli HN, \& Mallapur M. (2010). Improving Adherence to Oral Iron Supplementation During Pregnancy. Australian Medical Journal, 3(5), 10.

Bothwell TH. (2000). Iron Requirements in Pregnancy and Strategies to meet them Am J Clin Nutr, 72, 8.

Burke RM, Leon JS, \& Suchdev PS. (2014). Identification, Prevention and Treatment of Iron Deficiency during the First 1000 Days. Nutrients, 2014(6), 20.

Ferrari RM, Siega-Riz AM, Evenson KR, Moos MK, \& Carrier KS. (2013). A qualitative study of women's perceptions of provider advice about diet and physical activity during pregnancy. NIH Public Access, 91(3), 14. 
Garg A, \& Kashyap S. (2006). Effect of Counseling on Nutritional Status During Pregnancy. Indian J Med Res, 73(8), 6.

Girard AW, \& olude O. (2012). Nutritional Education and Councelling Provided During Pregnancy: effect on maternal, neonatal and child Health Outcomes. Pediatric and Perinatal Epidemiology, 26(1), 7.

Hyder SMZ, Persson LA, Chowdhury AMR, \& Ekstrom EC. (2002). Do Side effect Reduce Compliace to Iron Suplementation? Study of Daily and Weekly dose Regimen in Pregnancy. J Health Popul Nutr, 20(2), 5.

Kalaivani. (2009). Prevalence \& consequence of anemia in pregnancy. Indian $J$ Med Res, $130,7$.

Kementerian Kesehatan RI. (2014). Pedoman Gizi Seimbang. In D. B. G. d. KIA (Ed.), Nutritional Requirement (Vol. 2014). Jakarta: Kementerian Kesehatan RI.

Koura GK, Ouedraogo S, Port AL, Watier L, Cottrell G, \& Guerra J. (2012). Anaemia during pregnancy: impact on birth outcome and infant haemoglobin level during the first 18 months of life. Tropical Medicine and International Health, 17(3), 10.

Lawn JE, Causens S, \& Zupan J. (2005). 4 Millio Neonatal Death: When? Where? Why. Lancet, 365, 10.

Mariyam S, Yuliati, \& Rahayu T. (2007). Perilaku Konsumsi Tablet Fe Oleh Ibu Hamil Di Wilayah Kecamatan Ngawan Gunung Kidul Paper presented at the Penelitian, Pendidikan dan Penerapan MIPA pada 25 Agustus 2007 di FMIPAUNY, Yogyakarta.

Milman N. (2012). Oral Iron Prophylaxis in Pregnancy: Not Too Little and Not Too Much. Hindawi Publishing Corporation, 2012,8 .

Osborn CY, Amico K, Disher WA, Egede LE, \& Fisher J. (2010). An Information Behavior Skills Analysis of Diet and
Exercise Behavior in Puerto Ricans with Diabetes. $j$ health psychol, 15(8), 18.

Riskesdas. (2013). Riset Kesehatan Dasar. Retrieved from Jakarta:

Souza AID, Filho MB, Bresani CC, Ferreira LOC, \& Figueiroa JN. (2009). Adherence and Side Effect of three ferrous sulfate treatment regiment on anemic pregnant woment in clinical trials. Cad sude publica, 25(6), 9.

Stoltzfus RJ. (2011). Iron Intervention for Women and Chlidren in Low Income Countries. The Journal of Nutrition, 2011,7 .

Thirukkanesh S, \& Zahara AM. (2010). Compliance to Vitamin and Mineral Supplementation Among Pregnant Women in Urban and Rural Areas in Malaysia Pakistan Journal of Nutrition, 9(6), 6.

Thompson B. (2008). Food-Based Approaches For Combating Iron Deficiency. Rome.

Thorand B, Schultink W, Gross R, Sastro amidjojo S, \& Wentzel S. (1994). Efficiency of the Iron Supplementation Programme for Pregnant Women in Jeneponto, Sulawesi, Indonesia. Asia Pacific J Clin Nutr, 3, 5 .

WHO. (2011). Hemoglobin Concentration for the Diagnosis Of Anemia and Assesment of Severity. In W. H. Organization (Ed.), (Vol. 11). Geneva: VMNIS.

WHO. (2012a). Daily Iron and Folic Acid Supplement in pregnant Women. In W. H. Organization (Ed.). Geneva.

WHO. (2012b). Intermittent Iron and Folic Acid Supplementation in Non-Anemic Pregnant women. In W. H. Organization (Ed.). Geneva.

Yusoff H, Daud WNW, \& Ahmad Z. (2013). Effectiveness of Nutrition Education vs Non-Nutrition Education Intervention in Improving Awareness Pertaining Iron Deficiency Among Anemic Adolescent. Iranian J Publ Health, 42(5), 5. 